\title{
Book Review: Jens Lehne, Crisis at the WTO: Is the Blocking of Appointments to the WTO Appellate Body by the United States Legally Justified?
}

The US policy of blocking new appointments to the WTO Appellate Body relied on a number of legal arguments against the body's work and ultimately succeeded in rendering the appellate mechanism of the WTO dispute settlement system inoperable in December 2019. In his book, Jens Lehne carefully analyses the various legal arguments officially brought forward by the US until summer 2019. His analysis is proof of the vulnerability of the WTO: despite equality of WTO members enshrined in the WTO treaties, the fate of the WTO remains largely dependent on the willingness of large economies to comply with a legally binding dispute settlement system.

I. Introduction

II. Contents

\section{Citation:}

CHARLOTTE SIEBER-GASSER, Book Review: Jens Lehne, Crisis at the WTO: Is the Blocking of Appointments to the WTO Appellate Body by the United States Legally Justified?, sui generis 2020, S. 353 


\section{Introduction}

1 Lehne's book was published three months prior to the end of the WTO Appellate Body's operability in December 2019. The (temporary?) end of the appellate mechanism of the WTO dispute settlement came in the midst of a global trade war between the US, China and a considerable number of additional countries which were forced to react to unilateral trade measures of the US. Both the trade measures implemented by the US as well as the countermeasures introduced worldwide are of questionable compatibility with WTO obligations. In consequence, the number of WTO dispute settlement proceedings currently pending is soaring. ${ }^{1}$ The inoperability of the WTO Appellate Body, however, means that the resulting panel decisions in many of these on-going dispute settlement proceedings will ultimately be ignored. The WTO dispute settlement system is therefore currently unable to guarantee legal certainty and stability in the rules-based global trading system. Of course, the global COVID-19 pandemic which followed shortly after the (temporary?) removal of the WTO Appellate Body further increases the crisis of the multilateral trading system. Hence, the problem Lehne addresses in his book has already had far-reaching consequences and may potentially make history as the event which led to the destruction of the WTO-or more optimistically, to its modernisation and reform.

\section{Contents}

2 The book is roughly structured in three parts. First, Lehne addresses the chronology of the crisis. Troubles with (re-)appointments to the Appellate Body have a long history and traditionally the US played a critical role in them. Lehne lists all controversies surrounding (re-)appointments since the establishment of the Appellate Body (p. 5-11), and therewith explains that what followed under the Trump administration since 2017 does not constitute such a fundamental shift in US trade policy as many might suspect. In this first part of the book, Lehne furthermore discusses in detail the events taking place between February 2017 and July 2019 (p.13-27). Shortly after US president Trump took office, the US stopped effectively explaining their opposition to (re-)appointments and did no longer participate in attempts to craft consensus. This, as Lehne shows clearly, constituted a comparatively small change in US trade policy, however with far-reaching consequences.

1 In early July 2020, approx. 55 disputes were pending (counting only cases submitted after January 2018). For more information and a chronological overview, see WTO, Chronological list of disputes cases.
In the second and most substantial part of the book, 3 Lehne turns to the legal analysis of the official reasons provided by the US for the blockage of (re-)appointments to the Appellate Body. Lehne focuses on the US allegations of judicial overreach, which was at the time the official justification for the blockage. In the meantime, after having successfully removed the Appellate Body from the WTO dispute settlement system, the US have clearly stated that their allegations in the area of substantive law-particularly trade remedies, subsidies and the TBT Agreement-were their main and primary concern with the WTO dispute settlement system. Lehne explicitly refrains from analysing the merits of these allegations (p. 29) and instead focuses on what was officially known at the time of the publication of the book as the most substantive claims and justifications offered by the US: the alleged judicial overreach of the Appellate Body. Judicial overreach in itself is an important topic, meriting careful analysis independent from more recent US trade policy. Accusations of judicial overreach against international courts are weakening their authority-and therewith the authority of international law-substantially. As such, the WTO dispute settlement system is not an isolated case, and neither is it the first nor the last international dispute settlement system falling prey to its own success. Lehne's analysis of the extent to which the US allegations of judicial overreach were justified therefore informs not only the current discussion on reform and modernisation of the WTO, but also the broader international discussion on authority of international courts and of international law in general. Lehne reviews in particular the six examples presented by the US at the time as evidence of judicial overreach: 1) the so-called rule 15 (p.33), 2) the 90day deadline (p. 40), 3) the reliance on advisory opinions (p. 50), 4) the appellate review of facts (p. 66) and 5) of municipal law (70), and finally 6) the precedential effect of Appellate Body reports (p. 79). While answering the question whether the US allegations withstand legal scrutiny does not always result in a straight-forward "no", Lehne nevertheless concludes, in all six dimensions of the alleged judicial overreach, that the Appellate Body remained reasonable and largely within the boundaries as set out by the WTO treaties. He summarizes his conclusions as follows: "a close analysis of the six issues on procedure and interpretative approach presented by the US as prime evidence of its case against the Appellate Body simply does not bear out its claim that the Appellate Body is [...] a 'rule-breaking' runaway institution that has 'felt free to depart from what WTO Members agreed to'. Consequently, from a legal point of view these six issues, whether viewed individually or as a whole, do not even come close to justifying the US blockage of all appointments to the Appellate Body." (p.105). 
4 Hence, the reasons for the US blockage of (re-)appointments to the Appellate Body can clearly not be justified or even be explained on the basis of legal reasoning alone. In the third part of the book, Lehne therefore moves onto the broader context of the US blockage. While Lehne refutes the interpretation that the alleged judicial overreach is of such importance to the US so as to justify the elimination of the appellate mechanism altogether, he nevertheless notes that US frustrations with substantive law are long-running and authentic (p. 106). Lehne identifies unfulfilled expectations (p.108) as one reason for US discontent with the Appellate Body. Clearly, the Appellate Body assumed a more important role than was anticipated by the negotiators of the Uruguay Round. On the one side, far more disputes than anticipated were appealed (p.109). On the other side, the Appellate Body considered itself a fully-fledged international court for the rules of global trade, rather than simply the envisaged "second panel" (p.110-111). In addition, the US became not only the most active complainant, but were also leading in numbers of cases as respondent. While the US were winning most of their disputes as complainant, they were also losing most of their disputes as respondent (p.112-113).

5 Finally, Lehne draws attention to the misalignment between a very active judicial branch within the WTO and a virtually paralysed legislative branch. Negotiations since the founding of the WTO in 1995 have contrary to the previous track-record of the GATT 1947 not resulted in any major new agreement or treaty amendment (with the notable exception perhaps of the Trade Facilitation Agreement in 2013). This failure not only prevented the modernisation of WTO law, but also the necessary reforms of the dispute settlement system (p.114). Lehne therefore states: "In short, the US finds itself with an Appellate Body that has turned out to be more powerful than anticipated, has ruled against the US [...] far more frequently than expected, and is not checked by members through treaty amendments" (p.115). Lehne concludes, however, that the Appellate Body is not the reason for these unfulfilled expectations, rather he finds their origins in the initial WTO treaties, and in the fact that US expectations may have been unrealistic to begin with (p.116-119). Lehne concludes this final part of the book with a closer look at the particular nature of US trade policy under the Trump administration. He identi- fies primarily three changes to previous US governments: 1) a turn to mercantilism, 2) a preference for power-based instead of rule-based international trade relations, and 3) an opposition against multilateral institutions in general (p.123-124). Given the identified opposition by the Trump administration to legally binding dispute settlement in general, Lehne concludes that the US are currently not interested in a resolution of the appointment crisis (p.130). In consequence, one might argue that saving the two-stage dispute settlement system of the WTO without substantially reforming the WTO and its treaties may turn out to be unrealistic-at least as long as the Trump administration remains in office and/or the US remains a WTO member. However, the extent to which discontent with the Appellate Body and related substantive law of the WTO is shared by other WTO members has been overshadowed by the drastic measures taken the by Trump administration so far. It remains likely that the current crisis of multilateralism runs considerably deeper and that a number of other WTO members substantially share the concerns of the US.

\section{Appraisal}

This book was published in the middle of the current cri- 6 sis of multilateralism. We do not know yet whether and in what shape the rules-based global trading system and the WTO will re-emerge after this crisis. In "Crisis at the WTO”, Lehne shows that the accusation of "judicial overreach"-even though not withstanding legal scrutinywas indeed used by the US as a political justification to eliminate the inconvenient Appellate Body. The Appellate Body's work over the past 25 years should, however, not be blamed for the current crisis of multilateralism. Therewith, "Crisis at the WTO" is not only of interest to International Economic Law scholars and trade policymakers, but more broadly to all those interested in understanding and studying the role, design, and development of international courts and other international dispute settlement systems.

Reviewedbook:

"Crisis at the WTO: Is the Blocking of Appointments to the WTO Appellate Body by the United States Legally Justified?”, Jens Lehne, Carl Grossmann Verlag, Berlin/Bern 2019, ISBN: 978-3-941159-40-2 (printed edition, hardbound), ISBN: 978-3-941159-41-9 (e-Book, Open Access) 